\title{
Impact of chamber pressure and material properties on the deformation response of corneal models measured by dynamic ultra-high-speed Scheimpflug imaging
}

\author{
Impacto da pressão na câmara artificial e das propriedades do material sobre a resposta de deformação \\ de modelos de córnea medido por imagem de Scheimpflug ultradinâmica de alta velocidade
}

Fernando Faria Correia ${ }^{1,2,3}$, Isaac Ramos ${ }^{1,2}$, Cynthia J. Roberts ${ }^{4}$, Andreas Steinmueller ${ }^{5}$, Matthias Krug ${ }^{5}$, Renato Ambrósio JR. ${ }^{1,2,6}$

\begin{abstract}
Purpose: To study the deformation response of three distinct contact lenses with known structures, which served as corneal models, under different chamber pressures using ultra-high-speed (UHS) Scheimpflug imaging.

Methods: Three hydrophilic contact lenses were mounted on a sealed water chamber with precisely adjustable pressure: TAN-G5X (41\% hydroxyethylmethacrylate/glycolmethacrylate, $550 \mu \mathrm{m}$ thick), TAN-40 (62\% hydroxyethylmethacrylate, $525 \mu \mathrm{m}$ thick) and TAN-58 (42\% methylmethacrylate, $258 \mu \mathrm{m}$ thick). Each model was tested five times under different pressures $(5,15,25,35$ and $45 \mathrm{mmHg}$ ), using ultra-high-speed Scheimpflug imaging during non-contact tonometry. 140 Scheimpflug images were taken with the UHS camera in each measurement. The deformation amplitude during non-contact tonometry was determined as the highest displacement of the apex at the highest concavity (HC) moment.

Results: At each pressure level, the deformation amplitude was statistically different for each lens tested $(p<0.001$, ANOVA). Each lens had different deformation amplitudes under different pressure levels ( $p<0.001$; Bonferroni post-hoc test). The thicker lens with less polymer (TAN-G5X) had a higher deformation (less stiff behavior) than the one that was thinner but with more polymer (TAN-40), when measured at the same internal pressure. The thinnest lens with less polymers (TAN-58) had a lower deformation amplitude (stiffer behavior) at higher pressures than the thicker ones with more polymer (TAN-40 and TAN-G5X) at lower pressures.

Conclusions: UHS Scheimpflug imaging allowed for biomechanical assessment through deformation characterization of corneal models. Biomechanical behavior was more influenced by material composition than by thickness. Chamber pressure had a significant impact on deformation response of each lens.
\end{abstract}

Keywords: Cornea/physiology; Corneal topography/methods; Biomechanics; Tonometry, ocular/methods; Pressure

\section{RESUMO}

Objetivo: Estudar a resposta de deformação de três lentes de contato com estruturas conhecidas, que serviram como modelos de córnea, recorrendo à imagem descheimpflug de alta velocidade.

Métodos: Três lentes de contato hidrófilas foram montadas em uma câmara de água selada compressão ajustável:TAN-G5X (41\% hidroxietilmetacrilato/glycolmethacrylate

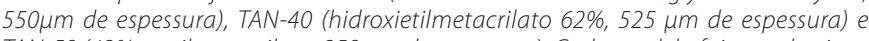
TAN-58 (42\% metilmetacrilato, 258 um de espessura). Cada modelo foi testado cinco vezes sob pressões diferentes $(5,15,25,35$ e $45 \mathrm{mmHg})$, recorrendo a um tonómetro de não-contato acoplado a uma câmara de Scheimpflug de alta velocidade. Cento e quarenta imagens de Scheimpflug foram capturadas em cada medição. A amplitude de deformação foi determinada como o maior deslocamento do ápice no momento de maior concavidade do modelo testado.

Resultados: Em cada nível de pressão, a amplitude de deformação foi estatisticamente diferente para cada lente testada ( $p<0,001$, ANOVA). Cada lente teve amplitude de deformação diferente sob distintos níveis de pressão $(p<0,001$; Bonferroni teste post-hoc). A lente mais espessa e com menos polímero (TAN-G5X) apresentou maior deformação (comportamento menos rígido) do que aquela que era mais fina mas com mais polímero (TAN-40), quando testadas sob a mesma pressão. A lente mais fina e com menos polímero (TAN-58) apresentou uma menor amplitude de deformação (comportamento mais rígido) sob pressöes mais elevadas, em comparação com as lentes mais grossas e com mais polímero (TAN-40 e TAN-G5X) em pressões mais baixas. Conclusões: A imagem de Scheimpflug de alta velocidade permite uma avaliação biomecânica a través da medição da amplitude de deformação dos modelos de córnea. O comportamento biomecânico foi mais influenciado pela composição do que pela espessura da lente. A pressão da câmara apresentou um impacto significativo sobre a amplitude de deformação de cada lente.

Descritores: Córnea/fisiologia; Topografia da córnea/métodos; Biomecância; Tonometria ocular/métodos; Pressão

\section{INTRODUCTION}

The knowledge of corneal biomechanics is fundamental to understanding the behavior of the cornea in certain corneal diseases and surgical procedures ${ }^{(1)}$. Keratoconus is an ectatic disease that derives from biomechanical weakening, characterized by corneal thinning and deformation ${ }^{(2-4)}$. Available treatments for this disease consist of placing intra-stromal rings and/or performing corneal collagen crosslinking ${ }^{(5)}$. These therapeutic modalities are aimed either to provide a supporting structure with intra-stromal rings or to stiffen the corneal stroma via crosslinking, with efficacy assessed by measuring corneal biomechanics ${ }^{(6-9)}$. Enhanced refractive surgery screening goes beyond corneal tomography and should include corneal biomechanics assessment. The main objective is to identify refractive candidates with an increased biomechanical susceptibility to post-LASIK ectasia ${ }^{(1,10,11)}$. Refractive surgery results are also influenced by the biomechanical response in changing the corneal shape $\mathrm{e}^{(12,13)}$.

Interest in corneal biomechanical properties began in laboratory studies using in vitro measurements. These measurements are
Submitted for publication: July 18, 2012

Accepted for publication: July 30, 2013

Study carried out at Oculus Gmb, Wetzlar, Germany

Physician, Instituto de Olhos Renato Ambrósio - Rio de Janeiro (RJ), Brazil.

Physician, Rio de Janeiro Corneal Tomography and Biomechanics Study Group - Rio de Janeiro (RJ), Brazil.

Serviço de Oftalmologia, Hospital de São João, Porto, Portugal.

$\mathrm{PhD}$, The Ohio State University - Columbus, OH, USA.

${ }_{5}$ Physician, Oculus Gmb, Wetzlar, Germany.

${ }^{6}$ PhD, Universidade Federal de São Paulo, São Paulo (SP), Brazil.
Funding: No specific financial support was available for this study.

Disclosure of potential conflicts of interest: F.F.Correia, None; I.Ramos, None; C.J.Roberts, consultant for Oculus; A.Steinmueller, employee of Oculus; M.Kurg, employee of Oculus; R.Ambrósio $\mathrm{Jr}$, consultant for Oculus.

Correspondence address: Renato Ambrósio Jr., Rua Conde de Bonfim, 211/712 - Rio de Janeiro (RJ) - 20520-050 - Brazil - E-mail: dr.renatoambrosio@gmail.com 
largely dependent on the experimental conditions and technique used, which limit their interpretation and comparison ${ }^{(6,14)}$. The Ocular Response Analyzer (Reichert) is a modified non-contact tonometer and represents the first clinical tool for assessing in vivo corneal biomechanical parameters ${ }^{(15)}$. The biomechanical measures provided by this system are Corneal Hysteresis $(\mathrm{CH})$ and Corneal Resistance Factor (CRF). Although the Ocular Response Analyzer (ORA; Reichert Ophthalmic Instruments, Buffalo, NY) was an attempt to provide corneal biomechanical information in addition to a more accurate estimate of intraocular pressure, the parameters produced are an assessment of viscoelastic behavior rather than a direct measure of elastic properties ${ }^{(14,15)}$. Despite being innovative, studies have shown low sensitivity and specificity of this device to diagnose disease, including keratoconus ${ }^{(4,16,17)}$.

New forms of in vivo assessment attempt to gain more direct and objective measurements of corneal biomechanical behavior. The Corvis ST (Oculus, Germany) is an ultra-high speed (UHS) Scheimpflug Technology Non-Contact Tonometer (NCT), which also provides biomechanical information. This is related to the dynamic imaging of corneal deformation induced by the air-puff. In addition to providing qualitative information through Scheimpflug imaging, it also provides quantitative information related to corneal biomechanics.

The purpose of this study is to evaluate and characterize the biomechanical behavior of three different types of contact lenses, under different chamber pressure levels, using the Corvis ST prototype. The analysis is focused on the influence of the chamber pressure, thickness and structural composition on the deformation amplitude of the lenses.

\section{METHODS}

The experimental study comprised of three hydrophilic contact lenses, which served as corneal models. Each lens was mounted on a sealed water chamber with precisely controlled adjustable pressure (Figure 1). Each lens had a well-known structure: the TAN-G5X was $550 \mu \mathrm{m}$ thick and had $41 \%$ hydroxyethylmethacrylate/glycolmethacrylate, the TAN-40 was $525 \mu$ m thick with $62 \%$ hydroxyethylmethacrylate and the TAN-58 was $258 \mu \mathrm{m}$ thick with $42 \%$ methylmethacrylate. Each lens or corneal model was tested consecutively five times under different pressures. Chamber pressures were adjusted to 5, 15, 25, 35 and $45 \mathrm{mmHg}$. Measures were taken by the Corvis ST (Oculus, Wetzlar, Germany) prototype. The room temperature and humidity were controlled and maintained constant at $20^{\circ} \mathrm{C}$ and $45 \%$ during the study.

The Corvis ST is an NCT with an UHS Scheimpflug camera, taking 4,330 frames per second. The $8 \mathrm{~mm}$ horizontal UHS Scheimpflug camera records 140 frames, which documents, in detail, the deformation movement of the cornea during NCT measurement ${ }^{(18)}$. The deformation amplitude (DA) during NCT was determined as the highest displacement of the apex at the highest concavity (HC) moment.

Statistical analysis was performed by using SPSS version 15.0 software (Chicago, IL, USA). ANOVA with Bonferroni post hoc pairwise comparisons were used to compare the DA of the different lenses under the same pressure levels studied and to compare the DA of each lens at the different pressure levels. Statistical significance was considered when the p value was less than 0.05 .

\section{RESULTS}

The mean and standard deviations of the measurements taken from each lens at each pressure are listed on table 1. The coefficient of variation (CV) was calculated as the ratio between the standard deviation and the mean value, multiplied by 100. The CV was level lower than 5\% for the three lenses at all pressure levels (Table 1). Figure 2 shows the deformation amplitude (DA) of the three different lenses under $5 \mathrm{mmHg}, 25 \mathrm{mmHg}$ and $45 \mathrm{mmHg}$ pressure levels.

For all pressure levels tested, the deformation amplitudes (DA) had statistically significant differences for all the three lenses $(p<0.001$, ANOVA test). There were also significant differences between each lens (Bonferroni post hoc pairwise comparisons, $\mathrm{p}<0.05$ ).

For all corneal-models tested, DA was significantly different on the diverse chamber pressure levels studied ( $p<0.001$, ANOVA test). Pairwise comparisons between the different levels of pressure for each lens showed statistically significant DA values in all comparisons (Bonferroni post-hoc pairwise test; $p<0.05$ ).

Figure 3 presents graphically the DA of each lens under different chamber pressures. As the chamber pressure increases, the deformation amplitude is lower for each lens. Interestingly, the thinnest lens with less polymer (TAN-58) had similar deformation amplitudes as TAN-G5X had when measured at chamber pressure set about 10 $\mathrm{mmHg}$ lower pressures and as TAN-40, when measured at about 20 $\mathrm{mmHg}$ lower pressures. Also, TAN-58 had less DA than TAN-G5X had when measured at $20 \mathrm{mmHg}$ lower pressures and as TAN-40, when measured at $30 \mathrm{mmHg}$ lower pressures.

\section{DISCUSSION}

In this study, biomechanical behavior of the corneal-model system made of soft contact lenses mounted on a sealed water chamber with adjustable pressure was assessed using the Corvis ST prototype.
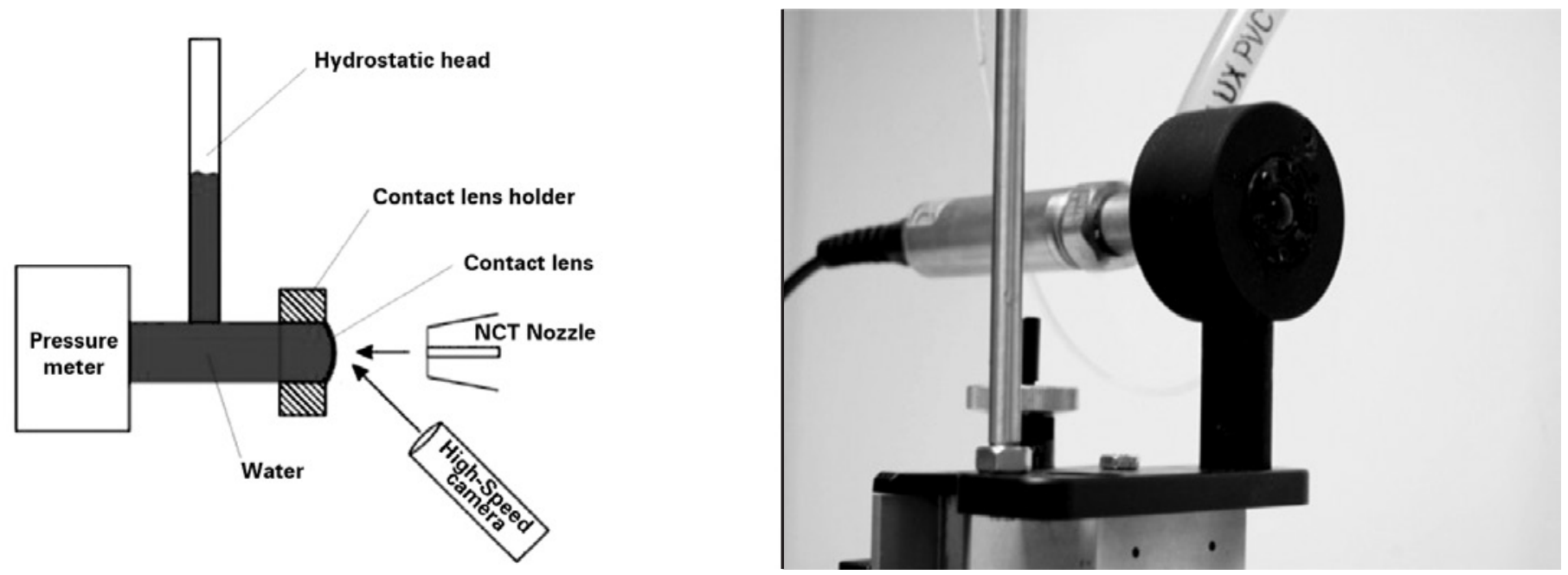

Figure 1. Sealed water chamber with precisely controlled adjustable pressure. 
Table 1. Mean, standard deviation (SD) and coefficient of variation (CV) for the three contact lens models at the different chamber pressure levels

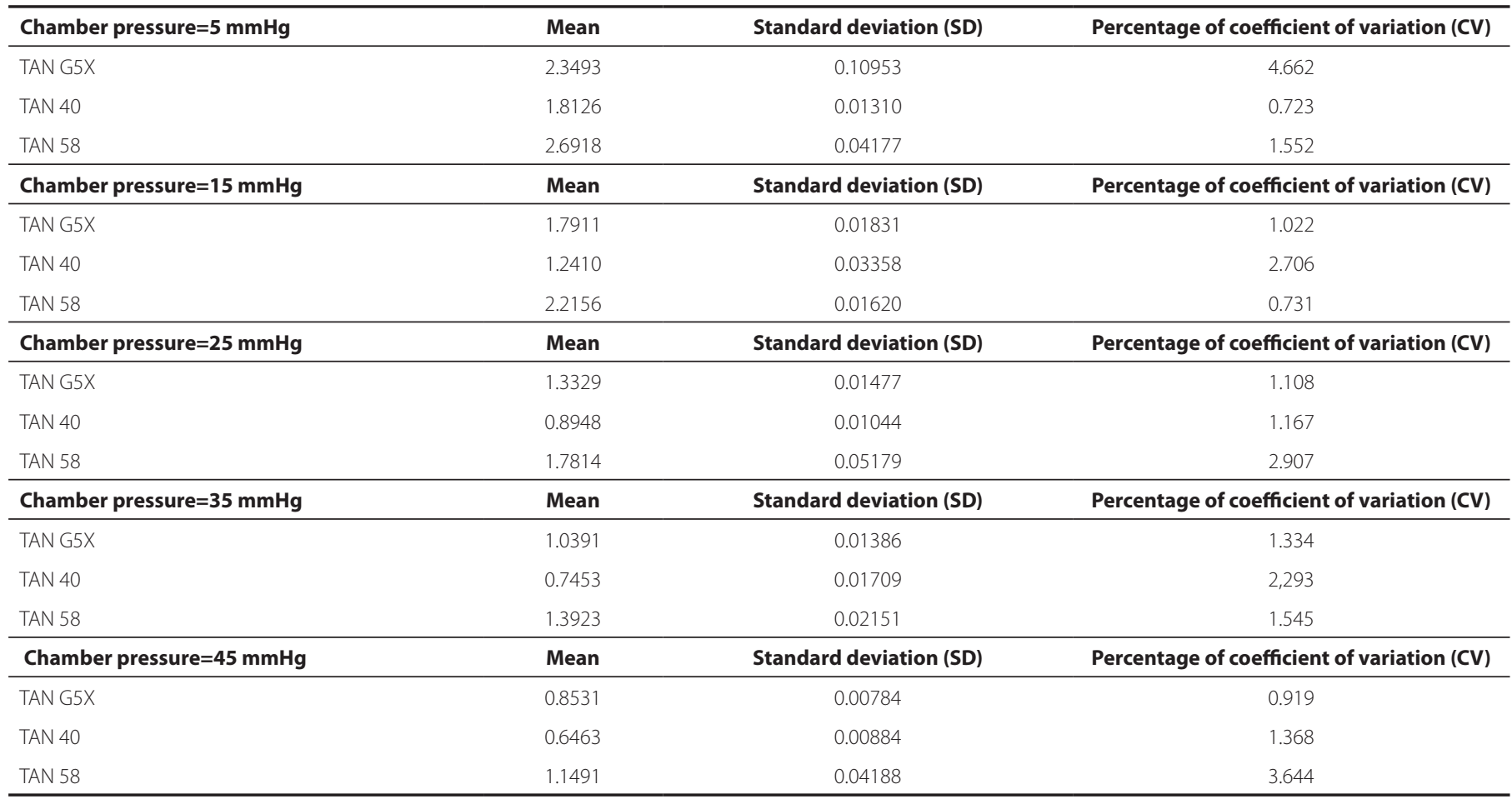

TAN G5X

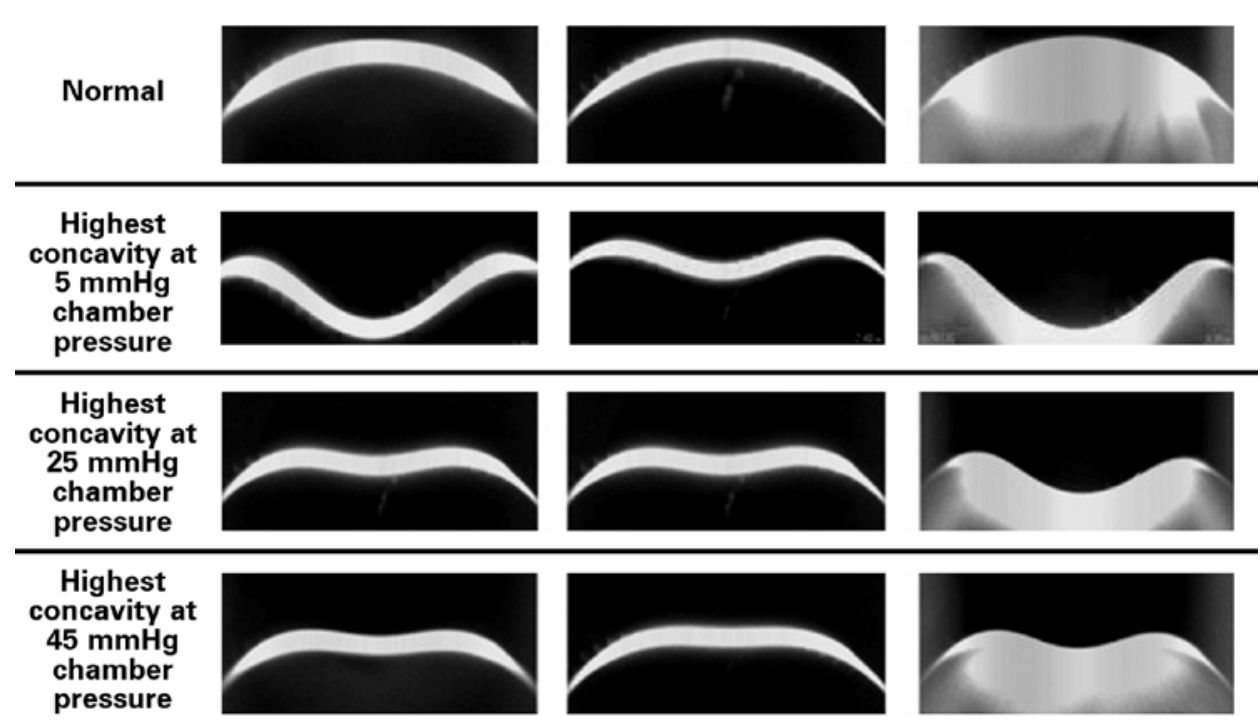

Figure 2. Deformation amplitude of the three different lenses under $5 \mathrm{mmHg}, 25 \mathrm{mmHg}$ and $45 \mathrm{mmHg}$ pressure levels.
This device is a new generation imaging system that provides in vivo biomechanical information, avoiding the limitations of prior in vivo and in vitro techniques ${ }^{(13,18)}$

Three distinct contact lenses with known structures and material compositions were tested under different chamber pressure conditions. Each lens-corneal model had different measured DA values. The DA also varied significantly accordingly to the chamber pressure. The internal pressure measurements are also related to certain features, namely the thickness and curvature of the lenses. Goldmann applanation tonometry is considered the gold standard for intraocular pressure (IOP) measurement in vivo(19). In fact, the sources of error in the measurement of IOP with this technique are well described. Ehlers et al. demonstrated that Goldmann applanation tonometry was accurate only if the central pachymetry was $520 \mu \mathrm{m}^{(20)}$. Doughty et al. found that 10\% $(50 \mu \mathrm{m})$ of corneal thickness difference induces an increase of $1.1 \mathrm{mmHg}$ with Goldmann applanation tonometry ${ }^{(21)}$. In 


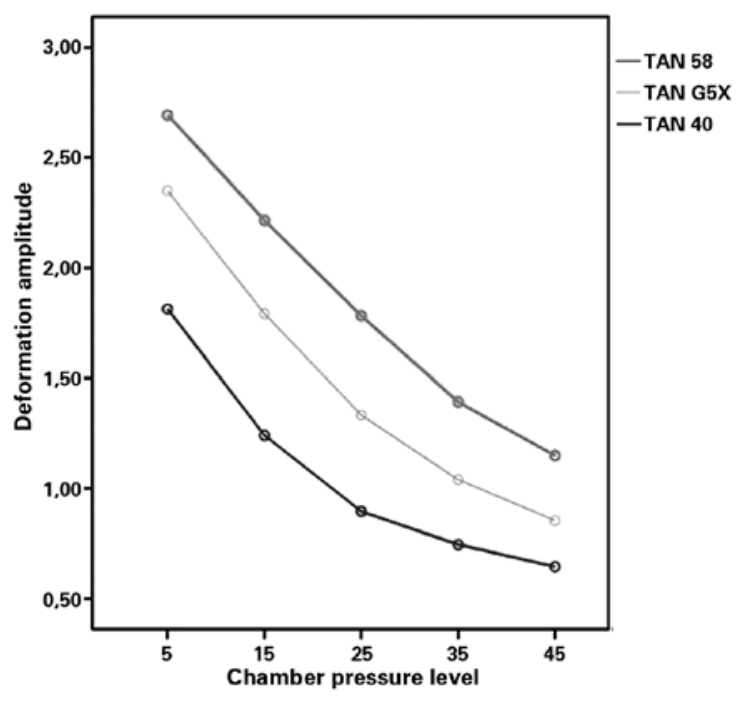

Figure 3. Graphic showing the values of DA (deformation amplitude) in different pressure levels for each of the contact lens.

addition, the thickness of the cornea has an influence on developing glaucomatous damage ${ }^{(22,23)}$. The knowledge of certain characteristics of the cornea, including the thickness, proves to be important for assessment of the true IOP value. On the same line of thought, corneal biomechanical properties also play an important role in the measurement of IOP(24).

Interestingly, if we compare the most pliable lens, the TAN-58, under the higher pressure of $35 \mathrm{mmHg}$, the DA is lower than the TAN-40 at $5 \mathrm{mmHg}$ and then the TAN-G5X at $15 \mathrm{mmHg}$. Also, the TAN-58 had similar DA at $25 \mathrm{mmHg}$ as TAN-G5X at $15 \mathrm{mmHg}$ and TAN40 at $5 \mathrm{mmHg}$. These results show that chamber pressure significantly influences the DA, independent of the corneal model thickness. Roberts et al. also reported that the IOP has the greatest influence on corneal deformation amplitude, compared with thickness and curvature ${ }^{(25)}$

The material composition was found more important than the thickness in the experiment. The thickest lens, TAN-G5X $(550 \mu \mathrm{m})$ had more DA than the TAN-40 (525 $\mu \mathrm{m})$, because the latter had more polymer compared to the first one (62\% hydroxyethylmethacrylate vs $41 \%$ hydroxyethylmethacrylate/glycolmethacrylate). However, thickness was also important, as the thinnest lens, TAN-58 $(258 \mu \mathrm{m})$ had more DA than the TAN-G5X (550 $\mu \mathrm{m})$, which had similar polymer composition. Similar results were already described in previous studies. Spoerl et al. and Dorronsoro et al. also reported the same relationship between the thickness and deformation response in porcine corneas ${ }^{(5,8,9)}$. Wollensack et al. and Elsheikh et al. reported lower deformations responses in human corneas compared with porcine ones ${ }^{(26,27)}$. This finding is indicative of a higher stiffness of the human cornea tissue despite its lower thickness. Other studies observed that corneas submitted to crosslinking, despite the decrease in thickness after the procedure, had different biomechanical behavior, reporting changes in the waveforms provided by the ORA ${ }^{(8,28)}$.

The deformation data obtained by the Corvis ST provide information related to the biomechanical properties of the tissue, but further investigation is necessary to quantify elasticity and viscoelasticity. As mentioned in previous studies, the chamber pressure level has a strong influence on the deformation response ${ }^{(18)}$. This new technology also helps in understanding of the variation of DA in corneamodels due to other parameters, such as thickness and structural composition. Thus, corneal biomechanical behavior is a function of multiple parameters, including IOP, corneal thickness and material composition. Further studies involving other biomechanical parame- ters provided by Corvis ST should be performed. Additionally, studies including human corneas should be designed.

\section{REFERENCES}

1. Dupps WJ Jr, Wilson SE. Biomechanics and wound healing in the cornea. Exp Eye Res. 2006:83(4):709-20.

2. Shah S, Laiquzzaman M, Bhojwani R, Mantry S, Cunliffe I. Assessment of the biomechanical properties of the cornea with the ocular response analyzer in normal and keratoconic eyes. Invest Ophthalmol Vis Sci. 2007;48(7):3026-31.

3. Fontes BM, Ambrósio R Jr, Jardim D, Velarde GC, Nosé W. Corneal biomechanical metrics and anterior segment parameters in mild keratoconus. Ophthalmology. 2010;117(4):673-9.

4. Piñero DP, Alio JL, Barraquer Rl, Michael R, Jiménez R. Corneal biomechanics, refraction, and corneal aberrometry in keratoconus: an integrated study. Invest Ophthalmol Vis Sci. 2010;51(4):1948-55.

5. Spoerl E, Huhle M, Seiler T. Induction of cross-links in corneal tissue. Exp Eye Res. 1998; 66(1):97-103.

6. Kling S, Remon L, Pérez-Escudero A, Merayo-Lloves J, Marcos S. Corneal biomechanical changes after collagen cross-linking from porcine eye inflation experiments. Invest Ophthalmol Vis Sci. 2010;51(8):3961-8.

7. Goldich Y, Barkana Y, Morad Y, Hartstein M, Avni I, Zadok D. Can we measure corneal biomechanical changes after collagen cross-linking in eyes with keratoconus? - a pilot study. Cornea. 2009;28(5):498-502.

8. Spoerl E, Terai N, Scholz F, Raiskup F, Pillunat LE. Detection of biomechanical changes after corneal cross-linking using Ocular Response Analyzer software. J Refract Surg. 2011;27(6):452-7.

9. Dorronsoro C, Pascual D, Pérez-Merino P, Kling S, Marcos S. Dynamic OCT measurement of corneal deformation by an air puff in normal and cross-linked corneas. Biomed Opt Express. 2012;3(3):473-87.

10. Ambrósio R Jr, Dawson DG, Salomão M, Guerra FP, Caiado AL, Belin MW. Corneal ectasia after LASIK despite low preoperative risk: tomographic and biomechanical findings in the unoperated, stable, fellow eye. J Refract Surg. 2010;26(11):906-11.

11. Binder PS. Ectasia after laser in situ keratomileusis. J Cataract Refract Surg. 2003;29(12): 2419-29. Comment in J Cataract Refract Surg. 2004;30(12):2460-1; author reply 2461-2.

12. Medeiros FW, Sinha-Roy A, Alves MR, Dupps WJ Jr. Biomechanical corneal changes induced by different flap thickness created by femtosecond laser. Clinics (São Paulo). 2011;66(6):1067-71

13. Ambrósio R Jr, Nogueira LP, Caldas DL, Fontes BM, Luz A, Cazal JO, et al. Evaluation of corneal shape and biomechanics before LASIK. Int Ophthalmol Clin. 2011;51(2):11-38.

14. Jue B, Maurice DM. The mechanical properties of the rabbit and human cornea. $J$ Biomech. 1986;19(10):847-53. Comment in J Biomech. 1991;24(9):869-72.

15. Luce DA. Determining in vivo biomechanical properties of the cornea with an ocular response analyzer. J Cataract Refract Surg. 2005;31(1):156-62.

16. Fontes BM, Ambrósio R Jr, Salomão M, Velarde GC, Nosé W. Biomechanical and tomographic analysis of unilateral keratoconus. J Refract Surg. 2010;26(9):677-81.

17. Fontes BM, Ambrósio R Jr, Velarde GC, Nosé W. Ocular response analyzer measurements in keratoconus with normal central corneal thickness compared with matched normal control eyes. J Refract Surg. 2011;27(3):209-15.

18. Ambrósio R Jr, Ramos I, Luz A, Faria FC, Steinmueller A, Krug M, et al. Dynamic ultra high speed Scheimpflug imaging for assessing corneal biomechanical properties. Rev Bras Oftalmol. 2013;72(2):99-102.

19. Goldmann H, Schmidt T. [Applanation tonometry]. Ophthalmologica. 1957;134(4):221-42. German.

20. Ehlers N, Bramsen T, Sperling S. Applanation tonometry and central corneal thickness. Acta Ophthalmol (Copenh). 1975;53(1):34-43.

21. Doughty MJ, Zaman ML. Human corneal thickness and its impact on intraocular pressure measures: a review and meta-analysis approach. Surv Ophthalmol. 2000; 44(5):367-408.

22. Medeiros FA, Sample PA, Zangwill LM, Bowd C, Aihara M, Weinreb RN. Corneal thickness as a risk factor for visual field loss in patients with preperimetric glaucomatous optic neuropathy. Am J Ophthalmol. 2003;136(5):805-13.

23. Herndon LW, Weizer JS, Stinnett SS. Central corneal thickness as a risk factor for advanced glaucoma damage. Arch Ophthalmol. 2004;122(1):17-21.

24. Liu J, Roberts CJ. Influence of corneal biomechanical properties on intraocular pressure measurement: quantitative analysis. J Cataract Refract Surg. 2005;31(1):146-55. Comment in J Cataract Refract Surg. 2006;32(7):1073-4; author reply 1074.

25. Roberts CJ, Mahmoud AM, Ramos I, Caldas D, Silva RS, Ambrósio Jr R. Factors influencing corneal deformation and estimation of intraocular pressure. ARVO Annual Meeting Abstract. 2011:E-abstract 4384.

26. Wollensak G, Spoerl E, Seiler T. Stress-strain measurements of human and porcine corneas after riboflavin-ultraviolet-A-induced cross-linking. J Cataract Refract Surg. 2003:29(9):1780-5.

27. Elsheikh A, Wang D, Rama P, Campanelli M, Garway-Heath D. Experimental assessment of human corneal hysteresis. Curr Eye Res. 2008;33(3):205-13.

28. Terai N, Raiskup F, Haustein M, Pillunat LE, Spoerl E. Identification of biomechanical properties of the cornea: the ocular response analyzer. Curr Eye Res. 2012;37(7):553-62. 